Tersedia online:http://journal.stainkudus.ac.id/index.php/jbe

\title{
PENGGUNAAN GUIDED TEACHING DALAM MENGORGANISASIKAN KONSEP PADA PEMBELAJARAN SISTEM PEREDARAN DARAH
}

\author{
Didi Nur Jamaludin
}

INSTITUT AGAMA ISLAM NEGERI KUDUS

Email: bioedu88@gmail.com

\begin{abstract}
ABSTRAK
Pembelajaran Biologi membutuhkan pemahaman konsep yang baik. Hasil observasi di MAN 1 Semarang, menunjukan ketuntasan belajar siswa klasikal pada materi sistem peredaran darah $67,5 \%$. Pemanfaatan media pembelajaran terus diupayakan, namun hasilnya belum memuaskan, sehingga diperlukan penelitian untuk mengetahui efektifitas metode guided teaching dalam mengorganisasikan konsep pada pembelajaran sistem peredaran darah. Metode penelitian menggunakan jenis weak eksperimental design tipe the one shot case study. Hasil penelitian diketahui bahwa rerata tingkat persentase ketuntasan kelas eksperimen mencapai $85 \%$ dengan taraf signifikansinya 0,02 dan tingkat keaktifan belajar siswa kelas eksperimen 90,81\%. Berdasarkan hasil tersebut dapat disimpulkan bahwa melalui penerapan metode guided teaching dalam mengorganisasikan konsep efektif dapat meningkatkan ketuntasan hasil belajar dan aktifitas belajar siswa pada materi sistem peredaran darah.
\end{abstract}

Kata Kunci: Guided Teaching, Organisasi Konsep, Sistem Peredaran Darah

\begin{abstract}
The biological study needs a good understanding of concept. An observation result in MAN 1 Semarang, has showed that the student learned mastery of classical in blood circulation system in 67,5\%. The using of learning media is continuing and efforted, but the result is not satifying yet, so it is needed to make research as a tool to measure the effectiveness method of guided teaching in the field of learning concepts of blood circulation system. The research has used weak experimental design type is the one shot case study. The result has showed that average point of student class learning the precentage level of class experiment mastery comes to point of $85 \%$ by level of significancy 0,02 and student learning activity is $90,81 \%$. Based on that result can make conclusion that through applying guided teaching method in organizing the concept is effective, it can increase the mastering of study result and student learning activity on blood circulation system.
\end{abstract}

Keywords: Blood Circulation System, Concept Organization, Guided Teaching 


\section{PENDAHULUAN}

Proses belajar mengajar menjadi salah satu bagian yang mendapat perhatian serius dalam upaya peningkatan kualitas pendidikan, karena didalamnya mengandung kegiatan interaksi antara guru dan siswa serta komunikasi timbal balik yang berlangsung dalam situasi edukatif untuk mencapai tujuan belajar. Guru dalam interaksi proses belajar, perlu menanamkan suatu sikap dan nilai kepada siswa, sehingga guru tidak hanya sebagai pusat penyampaian materi melainkan guru dapat memberikan arahan dan bimbingan agar siswa dapat mandiri dalam mencari dan membangun pemahaman materi, karena proses belajar yang baik, tidak lagi berpusat pada guru (teacher centered learning), melainkan siswa menjadi pusat dalam pembelajaran (student centered learning).

Karakteristik materi Biologi memiliki obyek pembelajaran yang bersifat fakta-fakta yang memberikan kumpulan konsep, pada materi sistem peredaran darah, banyak dijumpai konsep-konsep Biologi yang bersifat abstrak dan hubungan antar konsep mempunyai saling keterkaitan. Hasil observasi di MAN 1 Semarang tahun 2009, sesuai standar kriteria ketuntasan minimal (KKM) materi sistem peredaran darah, ketuntasan belajar yang ditetapkan secara individual $\geq 66$, siswa yang tuntas belajar secara klasikal 67,5\%, meskipun pemanfaatan media pembelajaran sudah diupayakan, namun hasilnya belum memuaskan. Kesulitan siswa dalam memahami materi sistem peredaran darah, dikarenakan materi tersebut ada beberapa yang bersifat abstrak dan tingkat keaktifan siswa yang kurang dalam proses belajar mengajar, sehingga ini menjadi kendala dalam pencapaian ketuntasan belajar.

Upaya mengintegrasikan pemahaman konsep struktur, fungsi dan proses sistem peredaran darah manusia yang saling berhubungan dengan realitas kehidupan serta memiliki korelasi dengan materi Biologi lainnya, sehingga diperlukan formulasi membangun konsep yang dapat mengaitkan hubungan antar konsep dengan realita kehidupan. Salah satu strategi yang diharapkan dapat membantu siswa dalam memahami konsep-konsep abstrak adalah dengan latihan mengorganisasikan konsep (Erman 2006). Dalam kegiatan ini, siswa dilatih mengidentifikasi konsep, setelah melaksanakan kegiatan tersebut siswa diharapkan dapat memahami materi secara terstruktur dan menyeluruh. 
Metode pembelajaran yang dapat membantu dalam mengorganisasikan konsep salah satunya dengan guided teaching, metode tersebut merupakan suatu metode berupa pertanyaan terstruktur yang diberikan guru kepada siswa yang dijadikan panduan dalam proses belajar mengajar yang telah disesuaikan dengan Kompetensi Dasar (KD). Siswa dapat terlatih mandiri dalam membangun pemahaman materi (membangun pengatahuan), melalui mereka menjawab pertanyaan dari guru maupun siswa lain. Penggunaan metode guided teaching sebagai pendukung dalam mengorganisasikan konsep pada materi sistem peredaran darah manusia, dengan demikian diharapkan siswa dapat interaktif dalam proses belajar mengajar. Untuk membuktikan metode guided teaching dalam mengorganisasikan konsep, efektif pada pembelajaran materi sistem peredaran darah, maka penelitian ini perlu dilakukan.

\section{METODE PENELITIAN}

Metode penelitian menggunakan pre eksperimental design dengan tipe the one shot case study. Fraenkel dan Wallen (2007) menjelaskan penelitian the one shot case study merupakan jenis weak experimental designs dengan sebuah kelompok tunggal yang diberikan perlakuan untuk mengetahui pengaruh tersebut. Lokasi penelitian di MAN 1 Semarang dengan sampel penelitian kelas XI IPA yang diambil secara acak (random sampling). Variabel dalam penelitian ini, 1) variabel bebas berupa penggunaan metode guide teaching dalam mengorganisasikan konsep pada materi sistem peredaran darah, 2) variabel terikat meliputi hasil belajar dan aktifitas belajar siswa.

\section{HASIL DAN PEMBAHASAN}

Hasil penelitian metode guided teaching dalam mengorganisasikan konsep pada materi sistem peredaran darah meliputi hasil belajar, aktifitas belajar siswa, dan tanggapan siswa terhadap pembelajaran yang diterapkan.

1. Hasil Belajar Siswa Kelas Eksperimen

Hasil belajar siswa pada kelas eksperimen, diperoleh melalui postes pada Tabel 1. 
Tabel 1. Hasil Belajar Siswa Kelas Eksperimen

\begin{tabular}{clc}
\hline No & \multicolumn{1}{c}{ Komponen } & Hasil belajar \\
\hline 1 & Jumlah Siswa & 40 \\
\hline 2 & Nilai Tertinggi & 88 \\
\hline 3 & Nilai Terendah & 28 \\
\hline 4 & Rata-Rata & 71,82 \\
\hline 5 & Taraf Signifikansi & 0,02 \\
\hline 6 & Persentasi Ketuntasan & $85 \%$ \\
\hline
\end{tabular}

2. Aktifitas Belajar Siswa Kelas Eksperimen

Hasil aktifitas belajar siswa pada kelas eksperimen, diperoleh melalui lembar observasi selama 5 kali pertemuan dijelaskan pada Tabel 2.

Tabel 2. Aktifitas Belajar Siswa Kelas Eksperimen

\begin{tabular}{|c|c|c|c|c|c|c|}
\hline \multirow[t]{2}{*}{ No } & \multirow{2}{*}{ Kriteria aktifitas belajar } & \multicolumn{5}{|c|}{$\begin{array}{c}\text { Persentase aktifitas belajar siswa } \\
\text { kelas eksperimen pada pembelajaran ke }\end{array}$} \\
\hline & & 1 & 2 & 3 & 4 & 5 \\
\hline 1 & Sangat aktif & $30 \%$ & $32,5 \%$ & $12,82 \%$ & $17,95 \%$ & $25 \%$ \\
\hline 2 & Aktif & $62,5 \%$ & $67,5 \%$ & $53,75 \%$ & $79,44 \%$ & $72,5 \%$ \\
\hline 3 & Kurang aktif & $7,5 \%$ & $0 \%$ & $33,33 \%$ & $2,56 \%$ & $2,5 \%$ \\
\hline 4 & Tidak aktif & $0 \%$ & $0 \%$ & $0 \%$ & $0 \%$ & $0 \%$ \\
\hline \multicolumn{2}{|c|}{ Persentase siswa sangat aktif dan aktif } & $92,5 \%$ & $100 \%$ & $66,57 \%$ & $97,49 \%$ & $97,5 \%$ \\
\hline \multicolumn{2}{|r|}{ Jumlah siswa } & 40 & 40 & 39 & 39 & 40 \\
\hline \multicolumn{7}{|c|}{ Persentase rata-rata siswa aktif dan sangat aktif $=90,81 \%$} \\
\hline
\end{tabular}

3. Tanggapan Siswa Kelas Eksperimen

Tangggapan siswa terhadap pembelajaran metode guided teaching dalam mengorganisasikan konsep di kelas eksperimen melalui lembar angket dari 21 siswa sebagai responden, diperoleh data pada Tabel 3.

Tabel 3. Hasil Angket Tanggapan Siswa Terhadap Pembelajaran Metode Guided Teaching

\begin{tabular}{|c|c|c|c|c|}
\hline \multirow{2}{*}{$\begin{array}{c}\mathrm{N} \\
\mathrm{o}\end{array}$} & \multirow{2}{*}{ Pertanyaan Responden } & \multicolumn{3}{|c|}{ Persentase jawaban } \\
\hline & & Ya & Tidak & Abstein \\
\hline 1 & $\begin{array}{l}\text { Metode guided teaching dalam mengorganisasikan } \\
\text { konsep membantu dalam memahami materi/konsep }\end{array}$ & $1100 \%$ & $0 \%$ & $0 \%$ \\
\hline 2 & $\begin{array}{l}\text { Metode guided teaching dalam mengorganisasikan } \\
\text { konsep membantu menghubungkan antar sub materi } \\
\text { peredaran darah atau materi Biologi lainnya }\end{array}$ & $95,42 \%$ & $4,58 \%$ & $0 \%$ \\
\hline 3 & $\begin{array}{l}\text { Metode guided teaching dalam mengorganisasikan } \\
\text { konsep dapat meningkatkan semangat belajar }\end{array}$ & $85,72^{\prime}$ & $14,28 \%$ & $0 \%$ \\
\hline
\end{tabular}




\begin{tabular}{llccc}
\hline \multicolumn{4}{c}{} & \\
\hline 4 & $\begin{array}{l}\text { Metode guided teaching dalam mengorganisasikan } \\
\text { konsep dapat meningkatkan keaktifan belajar }\end{array}$ & $100 \%$ & $0 \%$ & $0 \%$ \\
\hline 5 & $\begin{array}{l}\text { Ada manfaat pembelajaran dengan metode guided } \\
\text { teaching dalam mengorganisasikan konsep }\end{array}$ & $100 \%$ & $0 \%$ & $0 \%$ \\
\hline 6 & $\begin{array}{l}\text { Ada kendala pembelajaran dengan metode guided } \\
\text { teaching dalam mengorganisasikan konsep }\end{array}$ & $42,86 \%$ & $57,14 \%$ & $0 \%$ \\
\hline
\end{tabular}

Guided teaching merupakan metode yang dilakukan dengan cara guru menanyakan satu atau lebih pertanyaan untuk membuka pengetahuan mata pelajaran atau mendapatkan hipotesis atau kesimpulan siswa dan kemudian memilahnya ke dalam kategori-kategori. Kategori-kategori atau konsep yang tercatat, menjadi acuan untuk diajarkan. Guided teaching dalam pembelajaran di perguruan tinggi disebut sebagai pengajaran terbimbing melalui dosen bertanya kepada mahasiswa satu atau lebih pertanyaan untuk mengetahui tingkat pemahaman mahasiswa atau untuk memperoleh hipotesis atau kesimpulan kemudian membaginya kepada kategori, metode tersebut merupakan pembelajaran kooperatif (cooperative learning) yang berbasis pembelajaran aktif, inovatif, kreatif, efektif dan menyenangkan (PAIKEM) serta berguna pada pengajaran konsep-konsep abstrak (Silberman 2009, Suprijono 2007, Zaini 2002).

Pembelajaran dengan menggunakan metode guided teaching urutan langkahnya sebagai berikut.

1. Menyampaikan beberapa pertanyaan kepada siswa untuk mengetahui pikiran dan kemampuan yang mereka miliki.

2. Memberikan waktu beberapa menit untuk memberi kesempatan kepada siswa untuk menjawab pertanyaan.

3. Memberi kesempatan kepada siswa untuk menyampaikan hasil jawaban mereka dan catat jawaban-jawaban yang mereka sampaikan. Jika memungkinkan tulis di papan tulis dengan mengelompokan jawaban siswa dalam kategori-kategori yang nantinya akan disampaikan dalam pembelajaran. 
4. Menyampaikan poin-poin (konsep) utama dari materi yang disampaikan guru dengan ceramah intreraktif.

5. Memberi kesempatan kepada siswa untuk membandingkan jawaban mereka dengan poin-poin (konsep) yang guru sampaikan (Suprijono 2007).

Hasil belajar menjadi alat untuk mengetahui pencapaian siswa dalam menguasai materi yang menjadi tujuan pembelajaran sekaligus menjadi indikator efektif atau tidaknya suatu metode pembelajaran guided teaching. Selain itu, hasil belajar sebagai indikator keberhasilan siswa dalam mengorganisasikan konsep pada pembelajaran sistem peredaran yang diterapkan di MAN 1 Semarang. Anni et al. (2006) berpendapat hasil belajar siswa sebagai indikator merupakan perubahan perilaku yang diperoleh setelah mengalami aktifitas belajar.

Penggunaan metode pembelajaran guided teaching menunjukkan nilai postes siswa dengan persentase ketuntasan belajar kelas eksperimen mencapai 85\% (Tabel 2). Uji statistika dengan menggunakan program SPSS menunjukkan nilai taraf signifikansinya sebesar 0.02 lebih kecil dari pada 0,05 sehingga hipotesis penelitian menunjukan bahwa penggunaan metode guided teaching dalam mengorganisasikan konsep diterapkan efektif dalam meningkatkan nilai ketuntasan belajar pada materi sistem peredaran darah di MAN 1 Semarang dan hasil belajar tersebut juga lebih baik dibandingkan kelas lainnya. Mulyasa (2006) berpendapat pembelajaran dikatakan berhasil apabila terjadi perubahan perilaku yang positif, pada diri siswa minimal $75 \%$ yang ditandai dengan ketuntasan hasil belajar siswa.

Penelitian lain juga menunjukkan bahwa metode guided teaching secara signifikan dapat meningkatkan ketuntasan pembelajaran matematika dengan metode guided teaching ini diterapkan pada siswa kelas VII SMP Negeri B Srikaton pada materi segi empat. Rata-rata hasil belajar siswa sebesar 80,08 dan persentase jumlah siswa yang tuntas sebesar $75 \%$ dengan hasil uji $t$ juga menunjukkan penerimaan hipotesis alternatif (Aini, 2015). Hasil penelitian yang serupa juga dilakukan oleh Wahyuni (2014) menyatakan bahwa strategi pembelajaran aktif tipe guided teaching terhadap pemahaman konsep matematis lebih baik dari hasil belajar matematika siswa dengan menggunakan pembelajaran konvensional. 
Pembelajaran dengan menggunakan organisasi konsep diteliti oleh Erman (2006) di SMUN 5 and SMUN 8 Kediri pada materi kimia dengan menggunakan strategi latihan mengorganisasikan konsep dapat meningkatkan pemahaman konsep abstrak siswa, kemudian penelitian tentang penggunaan peta konsep dilakukan oleh Azis dan Jair (2009) di sekolah Selangor Malaysia, pada mata pelajaran Sejarah, hasilnya menunjukan dapat meningkatkan pencapaian hasil belajar. Berdasarkan tiga sumber penelitian tentang konsep menunjukan, bahwa pemahaman konsep materi dapat mempengaruhi hasil belajar dan aktifitas siswa, hal tersebut tentunya didukung oleh strategi, model, metode serta pendekatan pembelajaran yang tepat.

Metode guided teaching dalam mengorganisisikan konsep, telah mendorong keaktifan siswa dalam menjawab pertanyaan, memberikan pengaruh terhadap otak untuk terlatih dalam memecahkan suatu permasalahan, sehingga keterlibatan siswa secara aktif dalam kegiatan pembelajaran akan memberikan daya ingat yang lebih, bila dibandingkan siswa hanya membaca teks atau mengingat sementara (Hartono, 2007). Melalui metode tersebut, siswa merefleksikan pengalaman pembelajaran menjadi pengetahuan yang baru. Trianto (2007) menyampaikan sebagai upaya dalam memasukan pemahaman materi kedalam memori jangka panjang, maka dapat dilakukan dengan cara latihan pengulangan organisasi informasi. Tingkat pemrosesan informasi, semakin banyak proses mental yang harus dilakukan terhadap stimulus, maka semakin banyak mengingat stimulus.

Ausubel (Dahar 1988, dalam Trianto 2007), berpendapat dalam membantu siswa menanamkan pengetahuan baru dalam suatu materi, sangat diperlukan konsep-konsep awal yang dimiliki siswa yang berkaitan dengan konsep yang akan dipelajari, itulah suatu proses belajar bermakna. Jeromer Burner (Dahar 1988, dalam Trianto 2007) dalam teori belajar penemuan (discovery learning) menyarankan agar siswa hendaknya belajar melalui partisipasi aktif dengan konsep-konsep dan prinsisp-prinsip agar mereka memperoleh pengalaman dan dapat pula melakukan eksperimen-eksperimen yang dapat memberikan prinsip-prinsip secara mandiri. John et al (2004) menyampaikan dalam mengkonstruksi konsep dapat dilakukan dengan membaca secara komprehensip, 
melalui strategi: 1) mengaktifkan pengetahuan awal, 2) membuat pertanyaan, 3) mencari informasi, 4) meringkas, 5) mengorganisasikan grafik/ tulisan dan 6) identifikasi struktur cerita.

Hasil tanggapan siswa terhadap pembelajaran guided teaching dalam mengorganisisikan konsep, berpendapat metode tersebut membantu dalam hal; pemahaman materi, menghubungkan antar materi, meningkatkan motivasi serta meningkatkan aktifitasnya. Melalui kegiatan belajar konsep ada beberapa manfaat yang diperoleh siswa sebagai berikut:

1. mengurangi beban berat memori karena kemampuan manusia dalam mengategorisasikan beberapa stimulus terbatas,

2. merupakan unsur-unsur pembangun berpikir,

3. merupakan dasar proses mental yang lebih tinggi,

4. diperlukan untuk memecah masalah (Suprijono 2007).

Penggunaan strategi pembelajaran yang tepat dapat menjadikan konsep yang rumit menjadi lebih mudah, dapat menghubungkan petunjuk konsep secara jelas dan pengajaran guru yang menjemukan menjadi pengajaran menyenangan (Bull dan Ma 2001). Guru dapat berinisiatif untuk menggunakan teknik pengajaran peta konsep pada semua mata pelajaran sebagai satu cara untuk meningkatkan minat dan pencapaian hasil belajar siswa (Aziz dan Jair 2009), senada dengan hal tersebut, guru menyampaikan bahwa pembelajaran menggunakan metode guided teaching dalam mengorganisasikan konsep dapat diterapkan dalam pembelajaran pada materi yang lain. Hal itu dibuktikan oleh Sitanggang (2016) menjelaskan bahwa penelitian model pembelajaran guided teaching diajarkan pada materi akutansi menunjukkan hasil belajar yang lebih tinggi dibandingkan model pembelajaran Konvensional pada siswa kelas XII IPS SMA RK Deli.

Berdasarkan Tabel 2 bahwa pertemuan pertama dan kedua menunjukan tingkat persentasi keaktifan tinggi dalam kategori sangat aktif dan aktif bila dibandingkan dengan pertemuan ketiga. Hal tersebut dikarenakan banyak siswa aktif melakukan studi pustaka, mencatat materi/konsep, berdiskusi, bertanya, dan berpendapat baik kepada guru maupun antar siswa. Pertemuan ketiga mengalami penurunan, hal itu dikarenakan guru pada pertemuan tersebut belum optimal 
dalam memberikan bimbingan dalam memberikan kesempatan diskusi, berpendapat, bertanya maupun membantu dalam mengorganisasikan konsep yang bersifat kontekstual maupun studi kasus. Rumusan pertanyaan yang menjadi bahan diskusi diantaranya tentang saat kita keluar darah, apa kandungan/ komponen dalam darah yang terlihat merah? Mengapa saat kita terluka, darah dapat tidak mengalir lagi? Bagaimana darah bisa mengangkut oksigen untuk diedarkan ke seluruh tubuh?.

Siswa pada pertemuan keempat mengalami peningkatan, karena kegiatan pembelajaran berupa praktikum yang ditunjang dengan metode guided teaching dalam mengorganisasikan konsep yang memberikan pertanyaan kepada siswa, sehingga menjadi stimulus untuk terlibat lebih aktif dalam kegiatan praktikum. Pertemuan kelima mengalami kenaikan tingkat aktifitas belajar siswa sangat aktif dikarenakan mereka terlibat aktif melakukan studi pustaka, mencatat materi/konsep, berdiskusi, bertanya, dan berpendapat baik kepada guru maupun antar siswa.

Kegiatan praktikum uji golongan darah dengan siswa yang belum menunjukan keaktifan belajar yang lebih baik, dipengaruhi oleh kesemangatan belajar kurang. Hal tersebut ditunjukan hasil tanggapan siswa 14,28\% (Tabel 3) kesemangatan belajar kurang pada pembelajaran menggunakan metode Guided Teaching dalam mengorganisasikan konsep. Kesemangatan dalam mengikuti proses belajar mengajar bersumber dari faktor internal dan eksternal dari diri siswa. Anni et al. (2006) berpendapat faktor-faktor yang mempengaruhi proses belajar mengajar, bersumber dari kontribusi internal dan eksternal.

a. Kondisi internal

Kondisi internal mencakup kesehatan organ tubuh, kondisi psikis; seperti kemampuan intelektual, emosional dan kondisi sosial; seperti kondisi bersosialisasi dengan lingkungan. kondisi ekternal

b. Kondisi eksternal

Kondisi ekternal berasal dari lingkungan luar siswa. Beberapa faktor yang mempepengaruhi tingkat kesulitan yang dipelajari, iklim, suasana lingkungan dan budaya belajar malasyarakat. 
Tanggapan siswa secara umum mengemukakan bahwa penggunaan metode guided teaching dalam mengorganisasikan dapat meningkatkan kesemangatan dan keaktifan siswa dalam belajar. Kesemangatan dan keaktifan di pengaruhi oleh motivasi siswa dalam belajar. Anni et al. (2006) menyampaikan tentang motivasi, bahwa motivasi mempunyai peranan yang besar dalam membuat siswa melakukan aktifitas belajar dan dapat juga menentukan berapa banyak siswa dapat belajar dari aktifitas yang dilakukan atau informasi yang dihadapi. Motivasi dapat berasal dari faktor ekstrinsik dan instriksik.

Soeparwoto et al (2006) menegaskan siswa yang menunjukan minat belajar, akan mempunyai keinginan mereka tetap walaupun akan menghadapi hambatan maupun kesulitan, sehingga kesiapan belajar yang dimilki akan memberikan pengaruh terhadap kemajuan walaupun sedikit demi sedikit dan bertahap. Cothran dan Kulinna (2008) menjelaskan partisipasi siswa aktif dapat dilakukan dengan cara memberikan pertanyaan serta menanggapi respon siswa secara positif, menggunakan pengalaman terstruktur, menggunakan beberapa instrumen dan metode variatif yang dapat melibatkan siswa lebih aktif. Nasution (2009) berpendapat pembelajaran konsep juga memberikan represantasi internal seseorang.

Keaktifan siswa dalam belajar, sebagai upaya untuk meningkatkan perhatian siswa terhadap materi yang diajarkan. Siswa dapat belajar, aktif, inovatif kreatif dan menyenangan menjadi harapan dalam proses belajar mengajar. Menurut Djamarah dan Zain (2002) menuturkan, dalam proses belajar mengajar perhatian siswa terhadap materi pelajaran sangat dituntut. Perhatian siswa akan mempengaruhi pencapaiaan tujuan pendidikan, tercapainya tujuan pembelajaran manakala siswa menacapai penguasaan materi yang diberikan dalam pertemuan kelas.

Pengaruh metode pembelajaran pada kelas eksperimen dengan menggunakan metode guided teaching dalam mengorganisasikan konsep, aktifitas siswa lebih banyak aktif mengerjakan jawaban soal yang diberikan guru melalui referensi studi pustaka, telah memberikan peluang siswa lebih aktif mandiri. Trianto (2007) menuturkan pemahaman materi yang diperoleh hanya dengan sikap perhatian saja tanpa adanya proses pengulangan, proses masuknya informasi 
lebih bersifat jangka pendek, sehingga usaha yang dilakukan siswa dalam memahami materi agar dapat tersimpan dalam memori jangka pajang, mereka harus ada usaha mandiri melalui proses pengulangan materi secara terus menerus.

Kriteria siswa yang tidak aktif, pada kelas eksperimen tidak ada, dikarenakan siswa secara umum melakukan aktifitas belajar minimal memperoleh skor 6 dalam aktifitas belajarnya, sehingga interpretasi aktifitasnya terendah kategori kurang aktif. Tanggapam guru juga menunjukan penggunaaan metode guided teaching dalam mengorganisasikan membantu siswa dalam meningkatkan keaktifan dan kesemangatan belajar. Data keaktifan siswa belajar dengan metode guided teaching termasuk kategori pembelajaran efektif (sebesar 90,81\% di Tabel 2), mengacu dengan pendapat Mulyasa (2006) bahwa keberhasilan suatu proses belajar mengajar memberikan acuan bahwa proses pembelajaran dikatakan berhasil dan berkualitas apabila minimal 75\% siswa terlibat secara aktif, baik fisik mental, maupun sosial dalam proses pembelajaran.

Pertanyaan-pertanyaan yang diberikan guru pada penerapan metode Guided Teaching dalam mengorganisasikan konsep, dapat menjadi salah satu teknik efektif untuk menjadikan siswa dapat belajar. Fungsi pertanyaan yang diberikan guru kepada siswa, menurut Kauchak dan Eggen (1998) diantaranya sebagai berikut.

a) Menilai pemahaman yang dimiliki (assessing current understanding)

Siswa yang mengalami kendala pembelajaran dengan menggunakan metode Guided Teaching dalam mengorganisasikan konsep pada materi sistem peredaran darah, tanggapannya cukup tinggi berkisar 42,86\% (Tabel 3). Kesulitan mereka umumnya dalam mengidentifikasikan konsep ataupun memahami suatu konsep pada materi, dari tanggapan siswa menunjukan beberapa siswa mengalami kesulitan dalam menghubungkan konsep yang satu dengan yang lain, hal tersebut memberikan peran bagi guru sangat besar dan harus lebih proaktif dalam membimbing konsep dan memberikan contoh konsep yang benar kepada siswa. Penggunaan metode pada kelas eksperimen secara umum 95,42\% (Tabel 3) siswa berpendapat dapat membantu menghubungkan antar sub materi peredaran darah atau materi biologi lainnya. 
Erman (2006) berpendapat kesulitan yang dialami siswa dalam pengorganisasian konsep seringkali siswa belum bisa mengindentifikasi konsep dalam suatu kalimat sampai paragrap. Kekurangan tersebut dapat diatasi dengan kemampuan guru dalam mengarahkan siswa dalam pembelajaran atau melalui diskusi kelompok, bahkan guru juga dapat memberikan pertanyaan-pertanyaan singkat untuk memberikan arah kepada siswa tentang suatu konsep yang belum teridentifikasi oleh siswa, dengan cara demikian siswa menjadi lebih mudah dalam memahami suatu konsep. Silberman (2009) menjelaskan bahwa metode guided teaching sangat tepat diterapkan pada materi khususnya yang bersifat abstrak, oleh karenanya dalam rangka peningkatan kualitas proses belajar mengajar metode tersebut sangat tepat dikombinasikan dengan metode, strategi ataupun model pembelajaran lainnya.

Peran guru dalam menerapkan metode guided teaching dalam mengorganisasikan konsep memiliki peran yang besar sebagai evaluator terhadap konsep yang dimiliki siswa. Dari evaluasi tersebut guru dapat memberikan bimbingan dan penguatan akan konsep-konsep yang benar, dengan cara demikian siswa bisa lebih memberikan pesan lebih kuat dalam memorinya, karena pemahaman yang mereka miliki berdasarkan, pada konsep yang mereka pahami secara mandiri. Tanggapan siswa menguatkan bahwa penggunaan metode guided teaching dalam mengorganisasikan konsep pada sistem peredaran darah, dapat membantu menghubungkan antar sub materi sistem peredaran darah atau dengan materi Biologi lainnya.

Magliaro et al. (2005) berpendapat guru dalam menjabarkan konsep materi, perlu dikaitkan dengan pemahaman awal siswa, melalui keaktifan dalam memberikan contoh konsep dan melakukan penilaian terhadap kemajuan pemahaman konsep. Sehingga siswa dapat terhindar dari konsep yang keliru, Mulyati (2005) belajar konsep hendaknya dapat memperbaiki konsep yang salah (ill defined concept). Teori pembelajaran berbasis kognitif menekankan agar siswa dapat menyimpan pengetahuan melalui memori jangka panjang. Jika siswa dapat menggunakan memori jangka panjang, maka siswa dapat menghubungakan pengetahuan secara terstruktur dan pengetahuan tersebut dapat digunakan ketika suatu saat diperlukan (Jamudin 2002, dalam Aziz dan Jair 2009). 
Pembelajaran menggunakan metode guided teaching dalam mengorganisasikan konsep pada sistem peredaran darah sudah tepat diterapkan pada Madrasah Aliyah (MA). Soeparwoto et al. (2006) menyampaikan bahwa usia 11 tahun ke atas merupakan tahapan formal operasional yakni pada tahap ini tiap individu dapat mengembangkan pikiran formalnya, mereka dapat menggunakan logika, rasio dan kemampuan abstraksinya, dengan melibatkan dalam suatu kegiatan akan memberikan pengaruh lebih positif dari pada sekedar menonton.

b). Meningkatkan motivasi pembelajar (increasing learner motivation)

Pertanyaan efektif dapat melatih siswa untuk berfikir penuh tantangan dan menyikapi masalah dengan penuh percaya diri. Pertanyaan yang telah didesain tujuannya akan memberikan kondisi efek meningkatkan motivasi siswa. Disamping itu, pertanyaan yang diberikan oleh guru, menjadikan siswa dapat mengukur tingkat penguasaan materi secara mandiri, sehingga mereka dapat mendiagnosa kesulitan materi, sekaligus dapat mengatur strategi fokus materi yang harus dipelajari secara mendalam, begitu juga dengan pembelajaran menggunakan metode Guided Teaching dalam mengorganisasikan konsep dapat meningkatkan motivasi siswa untuk terlibat aktif dalam pembelajaran.

c). Membimbing pembelajaran baru (guided new learning)

Pertanyaan guru sebagai aturan instruksional dapat membantu siswa untuk menghubungkan ide baru dan mengintegrasikan pembelajaran baru dengan pemahaman yang dimiliki. Pertanyaan pada metode guided teaching dalam mengorgaisasikan konsep memberikan pengaruh terhadap penguasaan materi lebih bersifat kontekstual dan berkesan, karena dibangun atas pengetahuan lama yang dimiliki siswa dan diperbaharuhi dengan pengetahuan baru. Strategi pertanyaan guru untuk menjadi efektif, harus dapat membuat siswa berfikir, sehingga harus dibuat perencanaan yang terbaik dan dalam pelaksanannya menjadi kurang bernilai jika tidak membuat siswa berfikir.

Guru dan siswa berpendapat ada manfaat penggunaan metode Guided Teaching dengan mengorganisasikan konsep pada materi sistem peredaran darah diantaranya dalam peningkatan pemahaman materi, aktifitas belajar dan motivasi belajar. Erman (2006) melibatkan siswa dalam pengorganisasian konsep dapat 
mengurangi kepasifan siswa dan memacu minat serta partisipasi mereka dalam proses belajar mengajar secara bermakna. Pengorganisasian konsep juga dapat melatih siswa untuk belajar efektif dan efisien. Melalui pengorganisasian konsep, siswa menjadi lebih proaktif dalam mengorganisasikan pengetahuan dan siswa berusaha mengkonstruk pengetahuannya.

Manfaat pengorganisasian konsep, bagi guru dapat menjadi alat diagnosis letak kesulitan siswa dalam memahami konsep pada suatu hirarki konsep. Melalui pengorganisasian konsep, guru dapat mengetahui konsep-konsep yang tidak atau belum dipahami siswa dengan benar, selain itu guru juga dapat mengetahui letak terputusnya rantai pemahaman siswa dalam suatu hirarki konsep yang saling berkaitan. Dengan demikian, guru dapat merumuskan tindakan yang efektif untuk membantu siswa dalam belajar bermakna (Erman dan Wismana dalam Erman (2006). Anni et al. (2006) mengingatkan bahwa guru dalam memberikan tugas hendaknya memperhatikan jangkauan kemampuan siswa dalam menyelesaikan tugas, jangan sampai menimbulkan titik balik yang menimbulkan efek negatif dalam pembelajaran, semestinya tugas-tugas yang diberikan, mendukung antara penguasaan materi dan tingkat perkembangannya.

Penggunaan metode guided teaching dalam mengorganisasikan konsep, jika dibandingkan peta konsep, sebetulnya kedua metode tersebut mempunyai kesamaan dalam pembentukan identifikasi dan hubungan antar konsep, namun ada beberapa perbedaan. Pembelajaran tersebut kegiatan identifikasi konsep dilakukan oleh siswa, berdasarkan pertanyaan yang diberikan guru untuk mengetahui kemampuan yang dimiliki siswa. Pembelajaran menggunakan peta konsep mempunyai dua tipe. Tipe pertama, peta konsep dibentuk melalui identifikasi konsep yang dilakukan siswa berdasarkan topik yang diberikan guru. Tipe kedua, pembelajaran peta konsep hanya sebagai media pembelajaran untuk melengkapi metode ceramah serta siswa hanya dikondisikan untuk aktif mendengarkan (Aziz dan Jair 2009, Erman dan Sukirman 2002 dalam Erman 2006), sehingga dapat dikatakan bahwa metode guided teaching dalam mengorganisasikan konsep merupakan pengembangan dari metode peta konsep. Guru dan siswa berpendapat penggunaan metode Guided Teaching dalam 
mengorganisasikan konsep pada pembelajaran sistem peredaran darah, dapat diterapkan pada materi Biologi yang lain ataupun materi pelajaran selain Biologi.

\section{KESIMPULAN}

Berdasarkan hasil penelitian dan pembahasan maka dapat disimpulkan metode guided teaching dalam mengorganisasikan konsep, efektif dapat meningkatkan ketuntasan hasil belajar sebesar $85 \%$, peningkatan aktifitas belajar siswa sebesar 90,81\% dan tanggapan yang positif dari siswa pada materi sistem peredaran darah di MAN 1 Semarang. Pertanyaan yang dikembangkan pada metode guided teaching dalam mengorgaisasikan konsep memberikan pengaruh terhadap penguasaan materi lebih bersifat kontekstual dan membantu kebermaknaan hubungan antar konsep.

\section{DAFTAR PUSTAKA}

Aini, N. D. (2015). Penerapan Metode Aktif Guided Teaching pada Pembelajaran Matematika Siswa Kelas VII SMP Negeri B. Srikaton Tahun Pelajaran 2014/2015. Lubuklinggau: STKIP PGRI Lubuk Linggau. Diunduh dari http://mahasiswa.mipastkipllg.com/repository/Diah\%20Nur\%20Aini.pdf.

Anni, C.T. Rifa'i RC, A. Purwanto, E. Purnomo, D. (2006). Psikologi Belajar. Semarang: UNNES Press.

Aziz, Z \& Jair N. (2009). Penggunaan peta konsep untuk meningkatkan pencapaian mata pelajaran sejarah bagi pelajar tingkatan dua (the use of concept maps in improving achievement in the subject of history for form two students). Jurnal Pendidikan Malaysia. 34 (1): 3-15. On line at http://www.pdfchaser.com.

Bu 1l, S \& Ma, Y. (2001). Raising learner awareness of language learning strategies in situations of limited resources. Interactive Learning Environments 9 (2): 171-200. On line at http:// www.ingentanconnect.com

Cothran, D.J. \& Kulinna P.H. (2008). Teachers' knowledge about and use ofteaching models. Education Periodicals 65 (3): 122. On line at http://www.findarticles.com.

Djamarah, S.B \& Zain, A. (2002). Strategi Belajar Mengajar. Jakarta: Rineka Cipta. 
Erman. (2006). Latihan mengorganisasi konsep untuk meningkatkan kemampuan siswa berpikir konkrit memahami konsep abstrak. Jurnal Pendidikan dan Pembelajaran. 13, (1):45-53.

Fraenkel, Jack R \& Wallen, Norman E. (2007).How To Design and Evaluate Reseach in Education. Edisi 6. New York: The Mc Graw Hill Companies.

Hartono, J. (2007). Filosofi, Pendekatan dan Penerapan Pembelajaran Metode Kasus untuk Dosen dan Mahasiswa. Yogyakarta: Andi.

John T. dkk. (2004). Increasing Reading Comprehension and Engagement Through Concept-Oriented Reading Instruction. Journal of Educational Psychology, 96 (3): 403-423. On line at http://www.cori.umd.edu.

Kauchak, D.P \& Eggen, P. (1998). Learning Teaching Reseach-Based Methode. United States of America (USA): A Viacom Company.

Nasution S. (2009). Berbagai Pendekatan dalam Proses Belajar Mengajar. Jakarta: PT Bumi Aksara.

Magliaro, S.G. Lockee, B.B. Burton. J. K. (2005). direct instruction revisited: a key model for instructional technology. Education Periodicals. 53 (4): 41. On line at http://www.pdfchaser.com.

Mulyasa, E. (2006). Kurukulum yang Disempurnakan pengembangan Standar Kompetensi dan Kompetensi Dasar. Bandung: PT Remaja Rosdakarya.

Rustaman, N.Y. dkk. (2003). Strategi Belajar Mengajar. Bandung: Jurs. Pendidikan Biologi FMIPA UPI.

Silberman, M. (2009). Acive Learning 101 Strategi Pembelajarn Aktif. Bandung: Pustaka Insan Mandiri.

Sitanggang, F. W. (2016). Pengaruh Model Pembelajaran Guided Teaching Terhadap Hasil Belajar Akuntansi Siswa Kelas XII IPS SMA RK Deli Murni Deli Tua T.A 2016/2017. Tesis. Universitas Negeri Medan. Diunduh dari http://digilib.unimed.ac.id/20525/

Soeparwoto. Hendriyani, R. \& Litfiah. (2006). Psikologi Perkembangan. Semarang: Unnes press.

Suprijono, A. (2007). Cooperative Learning Teori dan Aplikasi PAIKEM. Yogyakarta: Pustaka Pelajar.

Trianto. (2007). Model-Model Pembelajaran Inovatif Berorientasi Konstruktivistik. Jakarta: Prestasi Pustaka Publisher. 
Wahyuni, J. L. (2014). Penerapan Strategi Pembelajaran Aktif Tipe Guided Teaching Terhadap Pemahaman Konsep Matematis Siswa Kelas VIII MTs N Talaok Bayang. Jurnal STKIP-PGRI Sumatera Barat. Volume 1, No 1, $1-6$.

Zaini, H. (2002). Strategi Pembelajaran Aktif di Perguruan Tinggi. Yogyakarta: IAIN Sunan Kalijaga. 